\title{
Bone morphogenetic protein (BMP) ligands and receptors in bovine ovarian follicle cells: actions of BMP-4, -6 and -7 on granulosa cells and differential modulation of Smad-1 phosphorylation by follistatin
}

\author{
Claire Glister, C Fred Kemp and Philip G Knight \\ School of Animal and Microbial Sciences, University of Reading, Whiteknights, Reading RG6 6AJ, UK \\ Correspondence should be addressed to P G Knight; Email: p.g.knight@reading.ac.uk
}

\begin{abstract}
Given the paucity of information on the potential roles of bone morphogenetic proteins (BMPs) in the ruminant ovary we conducted immunolocalization and functional studies on cells isolated from bovine antral follicles. Immunocytochemistry revealed expression of BMP-4 and -7 in isolated theca cells whereas granulosa cells and oocytes selectively expressed BMP-6. All three cell types expressed a range of BMP-responsive type-I (BMPRIB, ActRI) and type-II (BMPRII, ActRII, ActRIIB) receptors supporting autocrine/paracrine roles within the follicle. This was reinforced by functional experiments on granulosa cells which showed that BMP-4, -6 and -7 promoted cellular accumulation of phosphorylated Smad-1 but not Smad-2 and enhanced 'basal' and IGF-stimulated secretion of oestradiol (E2), inhibin-A, activin-A and follistatin (FS). Concomitantly, each BMP suppressed 'basal' and IGF-stimulated progesterone secretion, consistent with an action to prevent or delay atresia and/or luteinization. BMPs also increased viable cell number under 'basal' (BMP-4 and -7) and IGF-stimulated (BMP-4, -6 and -7) conditions. Since FS, a product of bovine granulosa cells, has been shown to bind several BMPs, we used the Biacore technique to compare its binding affinities for activin-A (prototype FS ligand) and BMP-4, -6 and -7 . Compared with activin-A ( $K_{d}$ $0.28 \pm 0.02 \mathrm{nM} ; 100 \%$ ), the relative affinities of FS for BMP-4, -6 and -7 were 10,5 and $1 \%$ respectively. Moreover, studies on granulosa cells showed that preincubation of ligand with excess FS abolished activin-A-induced phosphorylation of Smad-2 and BMP-4-induced phosphorylation of Smad-1. However, FS only partially reversed BMP-6-induced Smad-1 phosphorylation and had no inhibitory effect on BMP-7-induced Smad-1 phosphorylation. These findings support functional roles for BMP-4, -6 and -7 as paracrine/autocrine modulators of granulosa cell steroidogenesis, peptide secretion and proliferation in bovine antral follicles. The finding that FS can differentially modulate BMP-induced receptor activation and that this correlates with the relative binding affinity of FS for each BMP type implicates FS as a potential modulator of BMP action in the ovary.

Reproduction (2004) 127 239-254
\end{abstract}

\section{Introduction}

Bone morphogenetic proteins (BMPs) are members of the transforming growth factor- $\beta$ (TGF $\beta$ ) superfamily of extracellular signalling molecules, which play multiple roles in the regulation of growth, differentiation and apoptosis of numerous cell types. Several BMPs have recently been implicated as autocrine/paracrine regulators of ovarian follicle development (Elvin et al. 1999, Shimasaki et al. 1999). For instance, BMP-4 and -7 are expressed by theca cells in the rat (Shimasaki et al. 1999), BMP-3 is expressed in human granulosa-lutein cells (Jaatinen et al. 1996), BMP-6 is expressed by mouse oocytes (Elvin et al. 2000) and BMP-15/growth differentiation factor (GDF)-9B and GDF-9 are expressed exclusively by oocytes (McGrath et al. 1995, Bodensteiner et al. 1999, Jaatinen et al. 1999, Elvin et al. 2000, McNatty et al. 2001). Furthermore, rat granulosa cells and oocytes express mRNA for the BMP receptor (BMPR) types IA, IB and II throughout follicle development (Shimasaki et al. 1999) whilst sheep granulosa cells and oocytes were recently shown to express BMPRIB and BMPRII (Wilson et al. 2001).

Like other members of the TGF $\beta$ superfamily, BMPs signal by binding to and forming heteromeric complexes with two types of serine/threonine kinase receptor (type-I and type-II) on the cell surface (Massague \& Chen 2000, Miyazono et al. 2000, Miyazawa et al. 2002). The type-II receptor transphosphorylates a type-I receptor, which in turn activates transcriptional regulators called Smads, 
which transduce the signal to the nucleus to modify gene expression. BMPs can bind to one of three type-II receptors (BMPRII, activin receptor (ActRIIA or ActRIIB) and one of three type-I receptors (BMPRIA, BMPRIB or ActRIA). Signalling specificity in terms of which Smad pathway is activated is largely determined by the type-I receptor recruited (Macias-Silva et al. 1998, Ebisawa et al. 1999). BMPs activate Smad-1, -5 and -8 pathways whereas activin and TGF $\beta$ activate Smad-2 and -3 pathways (Miyazono et al. 2000, Miyazawa et al. 2002).

Recently, the naturally occurring sheep mutations, Inverdale and Booroola, have been attributed to defects in the ovarian BMP system. The Inverdale phenotype arises from a mutation in the BMP-15 gene, which leads to increased ovulation rate in heterozygotes, and primary ovarian failure in homozygotes (Galloway et al. 2000). The Booroola phenotype is caused by a mutation in the BMPRIB gene, which results in increased ovulation rate and multiple births (Souza et al. 2001, Wilson et al. 2001). Taken together with recent in vitro studies on the effects of BMPs on rat ovarian cell steroidogenesis (Otsuka et al. 2000, 2001a,b, Lee et al. 2001), such evidence points to the BMP system as having a major regulatory role in the mammalian ovary, central to follicular recruitment and selection mechanisms. However, little is known about the interplay between the BMPs and other welldocumented intraovarian factors implicated in follicle regulation including insulin-like growth factors (IGF), inhibin-A, activin-A and follistatin (FS) (Adashi et al. 1992, Webb et al. 1999, Knight \& Glister 2001). In addition, there is little information available on the intrafollicular distribution and potential functional roles of BMPs and BMPRs in species other than the rat.

With the above points in mind, the overall aim of the present study was to seek evidence for a functional BMP system within bovine antral follicles. First, an immunocytochemical approach was used to examine the expression of three BMPs (BMP-4, -6 and -7) and their potential type-I (BMPRIB, ActRIA) and type-II (BMPRII, ActRIIA, ActRIIB) receptors within the three main follicle cell types - theca cells, granulosa cells and oocytes. Secondly, the ability of BMP $-4,-6$ and -7 to modify granulosa cell secretion of steroids and inhibin-related peptides under 'basal' and IGF-stimulated conditions was investigated. Thirdly, we used a quantitative immunocytochemical approach to determine whether exposure of granulosa cells to BMP-4, -6 and -7 or activin-A leads to increased accumulation of phosphorylated Smad-1 or -2. Fourthly, since FS is secreted by bovine granulosa cells in an IGF-responsive manner (Glister et al. 2001), we quantified the binding affinity of FS for activin-A and BMP $-4,-6$ and -7 and investigated the extent to which FS could neutralize activin- and BMPinduced phosphorylation of Smad-1/2.

\section{Materials and Methods Ovary collection and cell harvesting}

Ovaries were obtained from cattle slaughtered at random stages of the oestrous cycle at an abattoir. Follicles (4-6 $\mathrm{mm}$ diameter) were dissected from ovaries, aspirated, hemisected and a plastic inoculation loop used to remove the granulosa cell layer as previously described (Glister et al. 2001). Follicle halves were then vortexed vigorously to remove any remaining granulosa cells, and the medium was changed three times. Follicle halves were then examined under a dissecting microscope and the theca interna layer was gently peeled away from the basement membrane. Pooled theca layers were incubated with collagenase $(1 \mathrm{mg} / \mathrm{ml}$; Sigma) and trypsin inhibitor $(100 \mu \mathrm{g} / \mathrm{ml}$; Sigma) in a shaking water bath at $37^{\circ} \mathrm{C}$. After $30 \mathrm{~min}$ the cell layers were triturated with a Pasteur pipette and returned to the water bath for another $15 \mathrm{~min}$. Finally, any remaining undigested material was allowed to settle and the resulting theca cell-rich supernatant decanted and retained. Both granulosa and theca cell suspensions were pelleted by centrifugation ( $800 \mathrm{~g}$ for $10 \mathrm{~min}$ ) and resuspended in a fixed volume of phosphate-buffered saline (PBS) before being subjected to an osmotic shock treatment (Glister et al. 2001) to lyse any red blood cells present. Cells were pelleted and resuspended in culture medium (McCoy's 5A modified medium supplemented with $1 \%$ $(\mathrm{v} / \mathrm{v})$ antibiotic-antimycotic solution, $10 \mathrm{ng} / \mathrm{ml}$ bovine insulin, $2 \mathrm{mM}$ L-glutamine, $10 \mathrm{mM}$ HEPES, $5 \mu \mathrm{g} / \mathrm{ml}$ apotransferrin, $5 \mathrm{ng} / \mathrm{ml}$ sodium selenite and $0.1 \%$ bovine serum albumin (BSA); all purchased from Sigma). Granulosa cells also received $10^{-7} \mathrm{M}$ androstenedione supplementation. Cells were counted using a haemocytometer and viability was assessed using trypan blue. Viability was $24 \pm 2 \%$ (S.D.) for granulosa cells and $89 \pm 3 \%$ for theca cells ( $n=6$ cultures). Granulosa and theca cells $\left(75 \times 10^{3}\right.$ viable cells $/ 50 \mu \mathrm{l}$ per well) were dispensed into the wells of 96-well plates or 16-well chamber slides containing pre-equilibrated medium (with/without treatments) and incubated at $38.5^{\circ} \mathrm{C}$ in $5 \% \mathrm{CO}_{2}$ and $95 \%$ air for 6 days. Conditioned medium (with/without treatments) was removed and replaced with fresh media (with/without treatments) every $48 \mathrm{~h}$. Conditioned media samples were stored at $-20^{\circ} \mathrm{C}$ for immunoassay. At the end of the culture period, viable cell number was determined by neutral red dye uptake as described elsewhere (Campbell et al. 1996, Glister et al. 2001). Cumulus-oocyte complexes were retrieved from 3-8 $\mathrm{mm}$ follicles and denuded oocytes obtained using hyaluronidase treatment as described by Glister et al. (2003).

\section{Fixation and immunocytochemistry}

Denuded oocytes were fixed overnight in $4 \%$ paraformaldehyde in PBS (pH 7.4). Granulosa and theca cells cultured in chamber slides were fixed in the same manner for $30 \mathrm{~min}$. All subsequent stages of staining were the same 
for oocytes and adherent cells with the exception that cells were stained in the chamber slides while oocyte staining was carried out in $50 \mu \mathrm{l}$ droplets. Briefly, oocytes and cells were permeabilized using $0.1 \%$ Triton $\mathrm{X}-100$ in PBS (10 min), washed in PBS (2 $\times 5 \mathrm{~min})$ and blocked $(1 \mathrm{~h})$ in PBS containing $0.1 \% \mathrm{NaN}_{3}, 2 \% \mathrm{BSA}$ and $10 \%$ normal goat, donkey or horse serum (matched to the species in which secondary antibody was raised). After overnight incubation with primary antibody (or control IgG; see below) diluted in blocking buffer, specimens were washed $(3 \times 10 \mathrm{~min}$ in PBS) and incubated for $1 \mathrm{~h}$ with the secondary antibody (see below). After washing in $0.1 \%$ Triton X-100 in PBS for $1 \mathrm{~h}$ and then PBS $(3 \times 10 \mathrm{~min})$ specimens were mounted (Vectashield; Vector Laboratories, Peterborough, Cambs, UK) and imaged on a scanning laser confocal microscope (TCS-NT; Leica Lasertechnik $\mathrm{GmbH}$, Heidelberg, Germany). Settings on the microscope (i.e. laser intensity, photomultiplier voltage, contrast) were kept constant while capturing each series of related images to facilitate subsequent quantitative comparison of relative fluorescence intensities.

\section{Immunoassays}

Concentrations of inhibin-A were determined using the two-site IRMA described by Knight \& Muttukrishna (1994), which has a detection limit of $250 \mathrm{pg} / \mathrm{ml}$ and within- and between-assay coefficients of variation (CV) of 5.2 and 7.4\% respectively. Activin- $\mathrm{A}$ and $\mathrm{FS}$ levels were measured by ELISA (Knight et al. 1996, Tannetta et al. 1998), both with detection limits of $100 \mathrm{pg} / \mathrm{ml}$. Within- and betweenplate CV values were 8.7 and $10.2 \%$ for the activin-A assay and 5.1 and $8.3 \%$ for the FS assay. E2 levels were determined by RIA as described previously (Glister et al. 2001) with a detection limit of $1.5 \mathrm{pg} / \mathrm{ml}$ and within- and between-assay $\mathrm{CV}$ values of 5.6 and $6.0 \%$ respectively. Progesterone (P4) concentrations were measured by ELISA (Sauer et al. 1986) with a detection limit of $20 \mathrm{pg} / \mathrm{ml}$ and within- and between-assay CV values of 7.4 and $11.6 \%$ respectively.

\section{Experiment 1: immunodetection of BMP ligands and receptors in isolated oocytes, theca cells and granulosa cells}

Denuded oocytes, granulosa cells (cultured for 6 days) and theca cells (cultured for 6 days) were immunostained with mouse monoclonal antibody (class IgG2b) against recombinant human (rh) BMP-4 and affinity-purified goat polyclonal antibodies against rh BMP-6, BMP-7, BMPRIB, ActRIA, ActRIIA, ActRIIB and BMPRII. Controls used were mouse IgG2b and normal goat IgG. All antibodies and respective control IgGs were purchased from R\&D Systems (Abingdon, Oxon, UK) and used at a concentration of $5 \mu \mathrm{g} / \mathrm{ml}$. Secondary antibodies used were fluorescein-conjugated horse anti-mouse (Vector) and horse anti-goat (Sigma) both at a $10 \mu \mathrm{g} / \mathrm{ml}$ concentration.

\section{Experiment 2: effects of BMP ligands on secretion of steroids and inhibin-related peptides by granulosa cells}

Granulosa cells were cultured for $144 \mathrm{~h}$ with a range of doses of rh BMP-4, BMP- 6 and BMP-7 (0, 2, 10, $50 \mathrm{ng} / \mathrm{ml}$; R\&D Systems) both in the absence and presence of IGF-I analogue (0, 2, 10, $50 \mathrm{ng} / \mathrm{ml}$; Long R3 (LR3)-IGF-l; Sigma). Conditioned media were collected every $48 \mathrm{~h}$ for subsequent measurement of E2, P4, inhibin- $A$, activin- $A$ and FS secretion. At the end of the 6-day culture period viable cell number was determined by neutral red uptake assay.

\section{Experiment 3: effect of BMP ligands on phosphorylation of Smad-1 and -2 in granulosa cells}

After $144 \mathrm{~h}$ of culture in the absence and presence of IGF $(0,2,10$ and $50 \mathrm{ng} / \mathrm{ml})$, granulosa cells were exposed to BMP-4, BMP-6, BMP-7 or activin-A (50 ng/ml) for $1 \mathrm{~h}, 4 \mathrm{~h}$ or $24 \mathrm{~h}$ before fixing and immunostaining with affinitypurified rabbit polyclonal antibodies against phospho (p)-Smad-1 and pSmad-2 (Upstate, Botolph Claydon, Bucks, UK). Normal rabbit IgG (R\&D Systems) was used as a control. Antibodies and IgG controls were both used at a concentration of $5 \mu \mathrm{g} / \mathrm{ml}$. The second antibody used was Alexa 488-conjugated goat anti-rabbit $(10 \mu \mathrm{g} / \mathrm{ml}$; Molecular Probes, Leiden, The Netherlands). After image capture on the confocal microscope, the relative intensity of immunostaining achieved under each experimental condition was quantified using $\mathrm{NIH}$ Image 1.63 software by measuring the fluorescence intensity of 20 randomly selected areas of each image (each containing approximately $10-15$ cells).

\section{Experiment 4: comparison of binding affinity of FS for activin- $A$ and BMPs}

Experiments were performed using the Biacore 3000 surface plasmon resonance (SPR) instrument (Biacore International, Stevenage, Herts, UK) to quantify the binding affinity of FS for activin-A, BMP-4, BMP-6 and BMP-7. rhFS-288 (supplied by National Hormone and Pituitary Program, Torrance, CA, USA) was immobilized onto the surface of a CM5 sensor chip ( $\sim 500$ resonance units) according to the manufacturer's protocol (Biacore). Activin-A, BMP-4, BMP-6 and BMP-7 were passed over the chip at a flow rate of $30 \mu \mathrm{l} / \mathrm{min}$. BSA was immobilized on an adjacent lane of the CM5 chip ( $\sim 500$ resonance units) and also exposed to activin-A and the BMPs to serve as a control. Hepes-buffered saline $(10 \mathrm{mM}$ Hepes, $150 \mathrm{mM}$ $\mathrm{NaCl}, 3.4 \mathrm{mM}$ EDTA, $0.005 \%$ Tween 20, pH 7.4) was used for sample dilution and as a running buffer. Bound activin-A and BMPs were eluted from the FS-coated surface using $6 \mathrm{M}$ guanidine- $\mathrm{HCl}, \mathrm{pH}$ 7.4. All curves were corrected by subtraction of the blank and curves were evaluated using Biacore evaluation software. Each ligand, at a range of concentrations $(1.56,3.13,6.25,12.5$ and $25 \mathrm{nmol} / \mathrm{l})$, was run over separate immobilized FS and BSA lanes in three independent experiments. The lowest 
ligand concentration tested $(1.56 \mathrm{nmol} / \mathrm{l})$ approximated to the $50 \mathrm{ng} / \mathrm{ml}$ dose level used to challenge granulosa cells in experiment 5 below. Kinetic data, including dissociation constant $\left(K_{\mathrm{d}}\right)$ was calculated from each run using the Biacore evaluation software and the average $K_{\mathrm{d}} \pm$ S.E.M. $\quad(n=3$ determinations $)$ calculated for each ligand.

\section{Experiment 5: does FS inhibit BMP-or activin-induced Smad phosphorylation in granulosa cells?}

After $144 \mathrm{~h}$ of culture, granulosa cells were exposed for a further $4 \mathrm{~h}$ to activin-A, BMP-4, BMP-6 or BMP-7 (all at $50 \mathrm{ng} / \mathrm{ml}$ ). Before addition to the cells each of the four ligands had been preincubated for $2 \mathrm{~h}$ at room temperature with/without hrFS (0, 250 and $1250 \mathrm{ng} / \mathrm{ml})$. After fixation, cells were stained with rabbit antibody against pSmad-1 (in the case of BMP-treated cells), pSmad-2 (in the case of activin-A-treated cells) or normal rabbit IgG (both). Intensity of staining was quantified as outlined above in experiment 3 .

\section{Statistical analysis}

Unless stated otherwise numerical values are presented as means \pm S.E.M. and $P$ values $<0.05$ were considered to be statistically significant. Two-way ANOVA of data from four independent experiments was used to evaluate the effect of BMPs on hormone secretion by granulosa cells cultured with/without IGF. Results presented are for the final 96-144 $\mathrm{h}$ culture period during which responsiveness to the various test substances was greatest. Comparison of relative fluorescence intensities of cells immunostained with pSmad antibodies was made by one- and two-way ANOVA with results analysed separately for each of three experiments. Comparison of binding affinities of activin-A and BMP-4, -6 and -7 for FS was made by one-way ANOVA of results from three replicate Biacore experiments.

\section{Results}

\section{Immunostaining of BMP ligands in bovine granulosa cells, theca cells and oocytes}

Figure 1a shows representative staining of granulosa cells for BMP -4, -6 and -7 ligands. Positive immunostaining for BMP-6 was detected in granulosa cells, whereas specific immunofluorescence was absent from cells stained with BMP-4 and -7 antibodies relative to the signals in the respective IgG controls. In contrast, positive immunostaining for BMP-4 and -7 was detected in theca cells while BMP-6 staining was considerably weaker (Fig. 1b). The ooplasm of oocytes showed consistent positive immunostaining for BMP-6 but not BMP-4 or -7 (Fig. 1c). Considerable immunofluorescence was often observed in the zona pellucida but this was considered non-specific as it was present in all cases, including normal IgG controls. Additional control experiments (data not shown) in which each cell type was incubated with BMP antibodies preadsorbed with their respective ligand (BMP-4, -6 or -7 at $10 \mu \mathrm{g} / \mathrm{ml}$ ) confirmed the specificity of the above immunostaining pattern observed in granulosa cells, theca cells and oocytes.

\section{Immunostaining of potential BMP-responsive type-I and type-II receptors in bovine granulosa cells, theca cells and oocytes}

As shown in Fig. 2a granulosa cells showed clear immunostaining for the two type-I receptors examined (BMPRIB and ActRIA) and the three type-II receptors examined (BMPRII, ActRIIA and ActRIIB) when compared with the corresponding signal in IgG controls. All five receptor subtypes were also detected in theca cells (Fig. 2b), although staining with BMPRIB and BMPRII was weaker than in granulosa cells. As shown in Fig. 2C oocytes also showed clear immunostaining for both of the type-I receptors and all three type-II receptors examined. Considerable heterogeneity of staining was observed for receptor localization amongst individual oocytes.

\section{Effect of BMPs on basal and IGF-induced granulosa cell hormone secretion and cell number}

As reported previously (Glister et al. 2001, 2003), the LR3-IGF-I analogue promoted significant $(P<0.005-$ 0.0001) dose-dependent increases in E2, P4, inhibin-A, activin-A and FS secretion and cell number, with maximum stimulation seen during the final $48 \mathrm{~h}$ period of culture (data not shown). The effects of BMP-4, -6, and-7 were tested at a range of doses $(0,2,10,50 \mathrm{ng} / \mathrm{ml})$ in the presence and absence of three doses of IGF analogue $(0$, 2, 10, $50 \mathrm{ng} / \mathrm{ml})$. As shown in Fig. 3A, when cultured under 'basal' conditions (i.e. in the absence of IGF stimulation) all three BMPs tested caused significant $(P<0.05-$ 0.0001 ) dose-dependent increases in E2, inhibin-A, activin-A and FS secretion. Conversely, a dose-dependent inhibitory effect on P4 secretion was exerted by each BMP $(P<0.05)$. Two-way ANOVA revealed no statistically significant differences between the effects of BMP-4, -6 and 7 on 'basal' hormone secretion. BMP-6 and -7 , but not BMP-4, also promoted a small though significant increase in viable cell number $(P<0.05)$. Although BMP responses were greatest during the final 48-h culture period, BMPinduced secretion of activin and FS was already evident during the first 48-h period $(P<0.05)$ while BMP-induced secretion of inhibin, activin, FS and E2 was first detected during the second 48-h period $(P<0.05)$ (data not shown); these response-time courses were similar under both 'basal' and IGF-stimulated conditions.

When granulosa cells were co-treated with IGF analogue (Fig. 3B), all three BMPs caused dose-dependent increases in E2, inhibin-A, activin-A and FS secretion and cell number $(P<0.05-0.0001)$ while suppressing $\mathrm{P} 4$ secretion $(P<0.0001)$. A dose of $10 \mathrm{ng} / \mathrm{ml}$ IGF (data shown in Fig. 3B) gave the greatest fold-differences in 


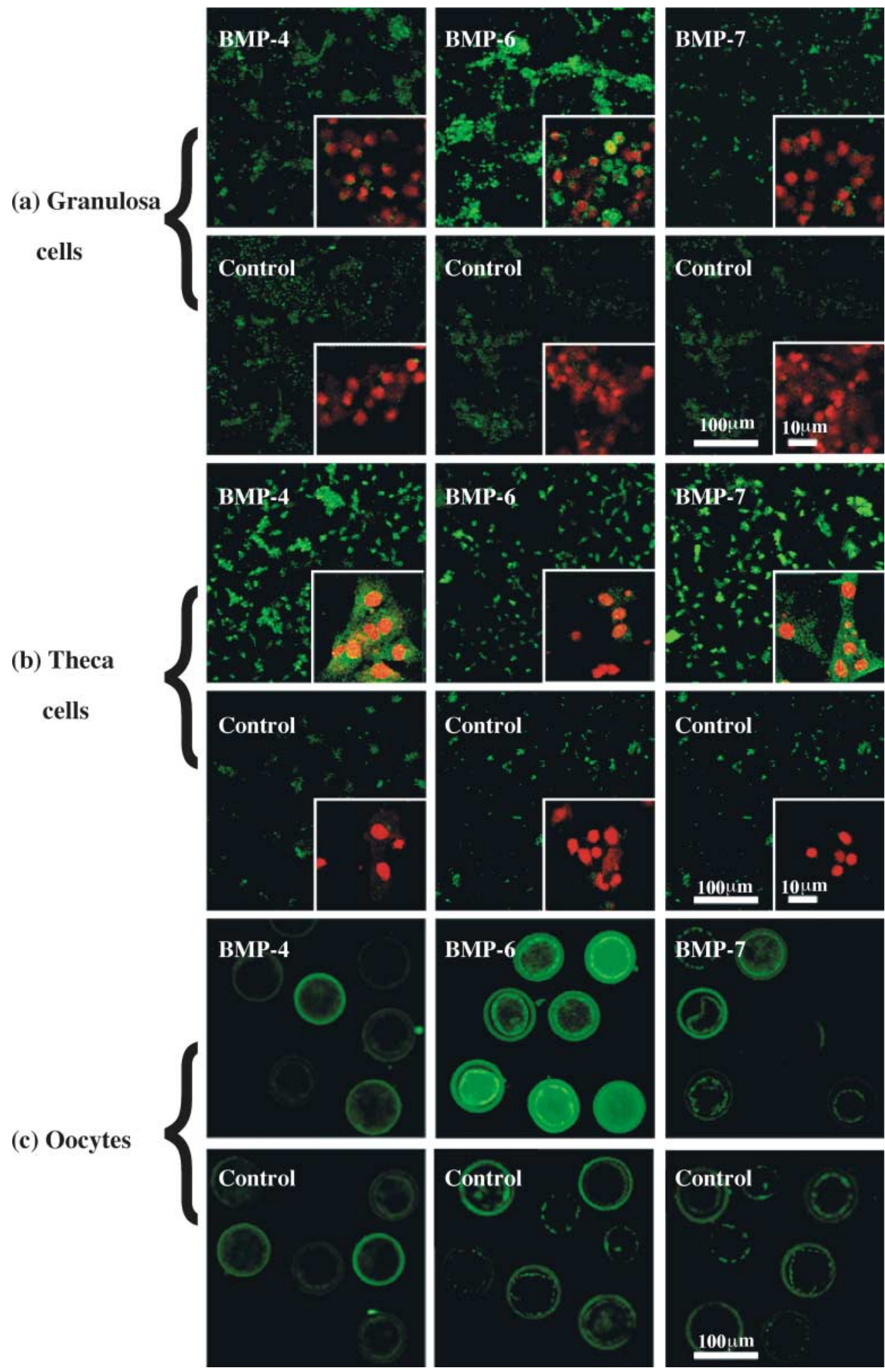

Figure 1 Representative low magnification ( $\times 16$ objective) confocal microscopy images showing immunostaining of BMP-4, BMP-6 and BMP-7 in (a) granulosa cells, (b) theca cells and (c) denuded oocytes from bovine antral follicles. Adjacent panels show corresponding controls in which specific anti-BMP IgG was replaced with species-matched normal IgG. The inset panels in (a) and (b) show higher magnification images ( $\times 63$ objective) of cells counterstained with propidium iodide (red nuclear staining). 
(a) Granulosa cells

(b) Theca cells

\section{(c) Oocytes}
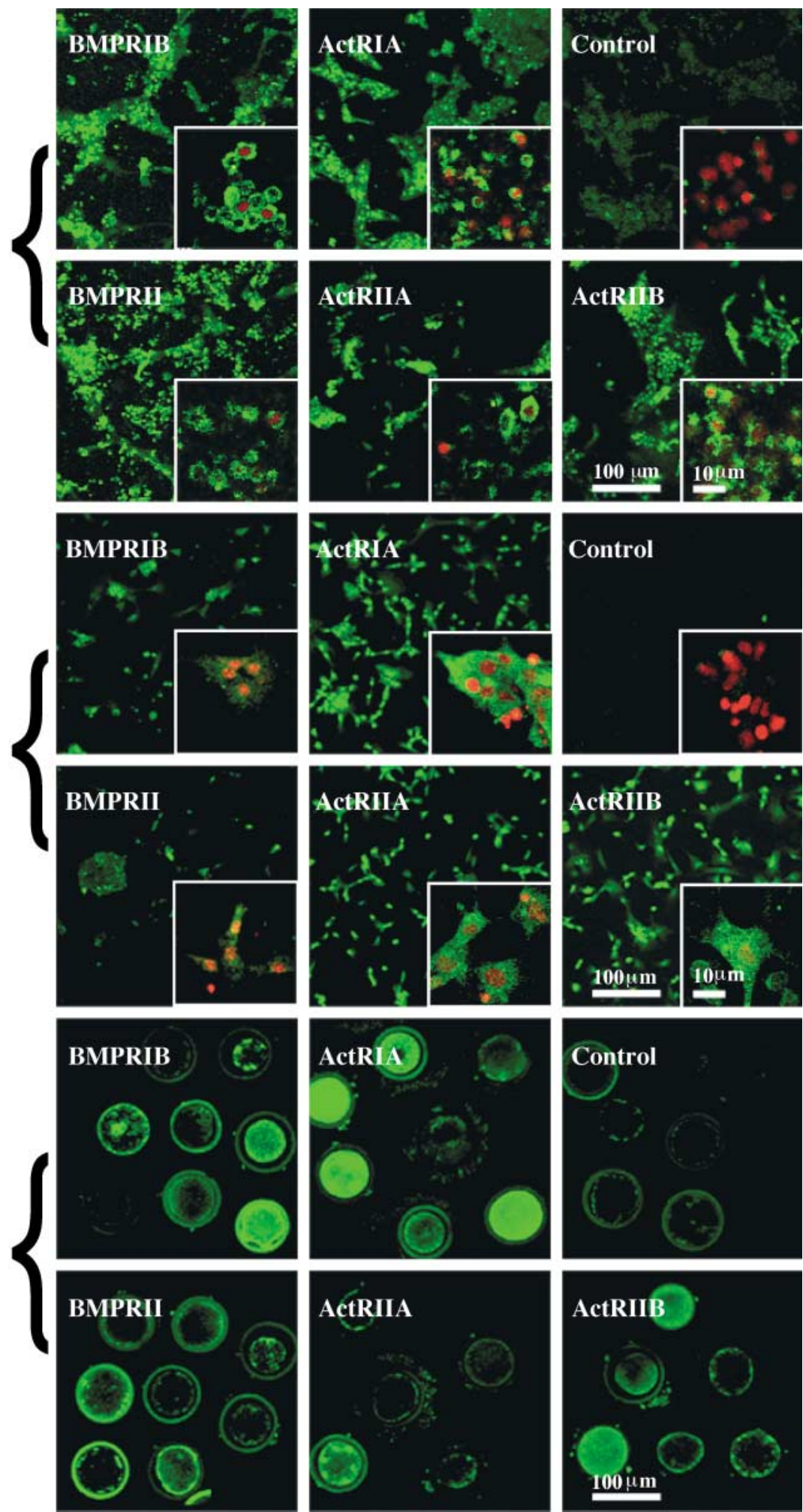

Figure 2 Representative low magnification ( $\times 16$ objective) confocal microscopy images showing immunostaining of BMPRIB, BMPRII, ActRIA, ActRIIA and ActRIIB in (a) granulosa cells, (b) theca cells and (c) denuded oocytes from bovine antral follicles. A panel showing control staining in cells incubated with normal goat IgG in place of specific goat anti-receptor IgG is presented. The inset panels in (a) and (b) show higher magnification images ( $\times 63$ objective) of cells counterstained with propidium iodide (red nuclear staining). 

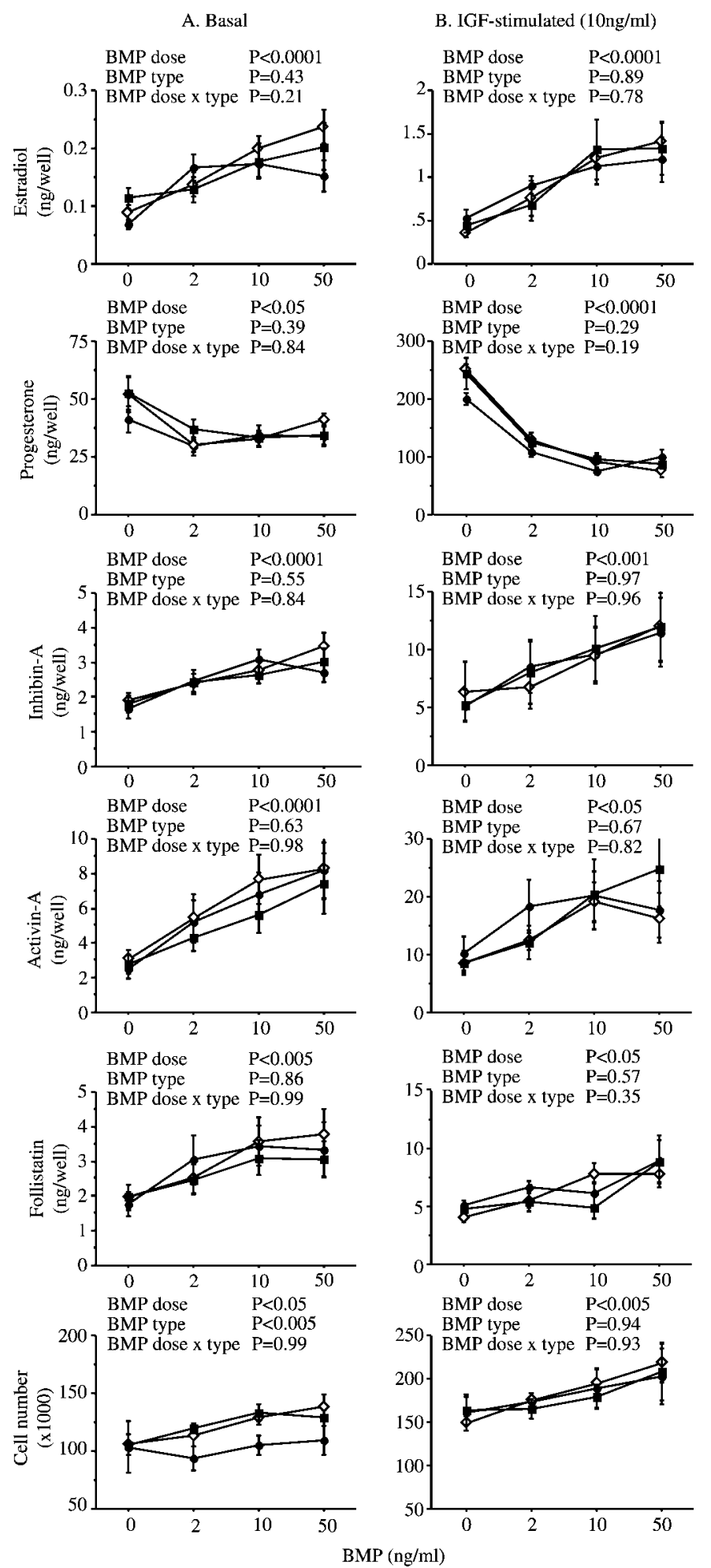

Figure 3 Effects of BMP-4 $(\bullet)$ BMP-6 $(\diamond)$ and BMP-7 $(\mathbf{\square})(\mathrm{A})$ alone and $(\mathrm{B})$ in the presence of LR3-IGF-I analogue $(10 \mathrm{ng} / \mathrm{ml}) \mathrm{on}$ the secretion of E2, P4, inhibin-A, activin-A and FS by bovine granulosa cells and on viable cell number at the end of the culture period. Values are means \pm S.E.M. ( $n=4$ independent cultures); results of two-way ANOVA are summarized. 
stimulation/inhibition of hormone secretion and cell number in the presence of the BMPs, with IGF doses of 2 and $50 \mathrm{ng} / \mathrm{ml}$ showing sub-optimal levels of stimulation/inhibition in comparison (data not shown). The effects exerted by BMPs, under both basal and IGF-stimulated conditions, were greatest at the highest dose of BMP tested $(50 \mathrm{ng} / \mathrm{ml})$; limited supplies precluded the testing of higher BMP doses in these experiments.

\section{Immunodetection of phosphorylated Smad-1 and Smad-2 in granulosa cells after stimulation with BMPs $-4,-6$ and -7 and activin- $A$}

In preliminary experiments (data not shown) granulosa cells were treated with BMP-4, $-6,-7$ or activin-A for a period of $1 \mathrm{~h}, 4 \mathrm{~h}$ or $24 \mathrm{~h}$ prior to fixation and immunostaining with pSmad-1 or pSmad-2 antibodies. Since a 4-h treatment period was found to give optimal signals in terms of pSmad accumulation, this incubation period was selected for all subsequent experiments. As expected, pSmad was mainly localized in the nucleus (Fig. 4). Representative staining of granulosa cells cultured for 6 days under basal and IGF-stimulated conditions and then treated for $4 \mathrm{~h}$ with BMP-4, -6 or -7 , before staining with an anti-pSmad-1 antibody is shown in Fig. 5. In the presence of BMP-4, -6 or -7 intense immunofluorescence staining was observed with the pSmad-1 antibody, whilst very little staining was detected in cells stained with pSmad-1 antibody in the absence of BMP treatment or in normal rabbit IgG-treated controls. When relative fluorescence signals were quantified (see histograms in Fig. 5) the level of pSmad-1 in cells cultured under basal conditions after BMP-4 and -7 stimulation was significantly $(P<0.0001)$ elevated with respect to controls. BMP-6-treated cells also showed a modest increase in pSmad-1 levels $(P<0.05)$. (a)

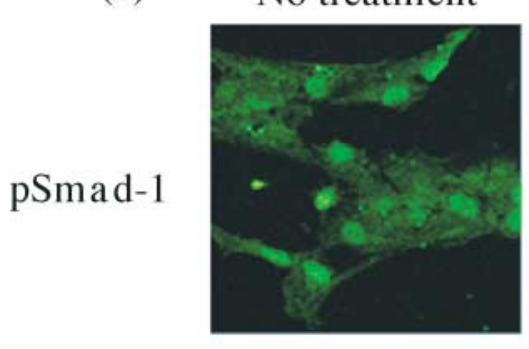

Control

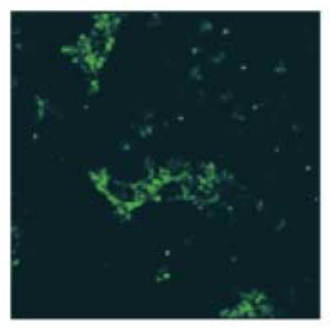

(b)
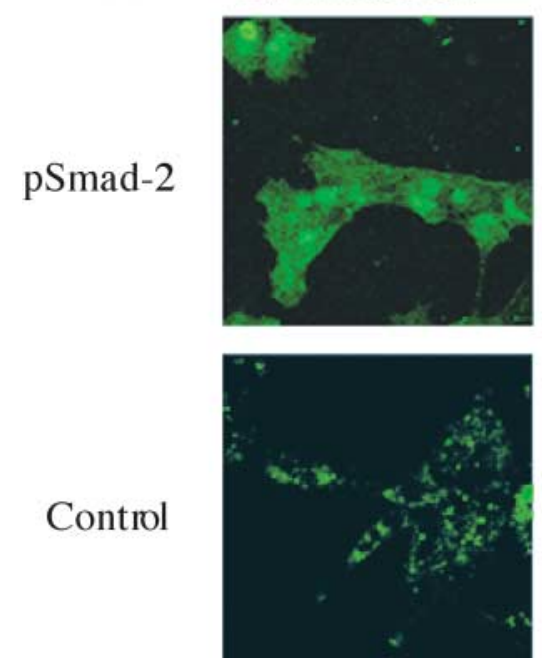

BMP-4
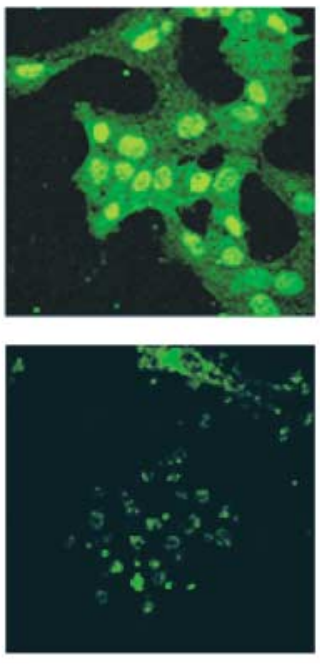

Activin-A
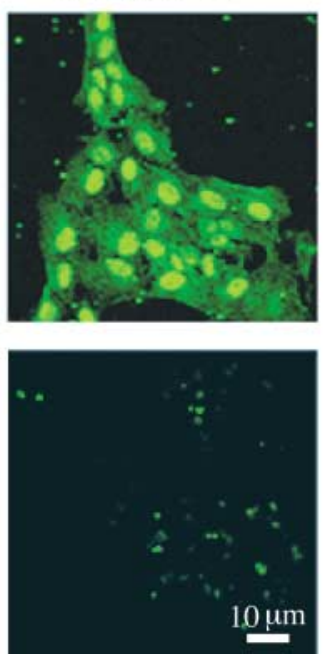

BMP-6
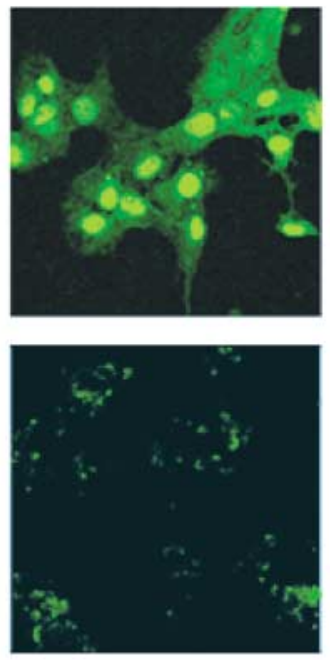

BMP-7
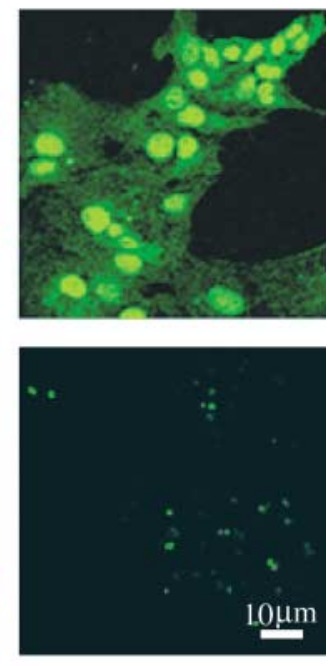

Figure 4 Representative high power ( $\times 63$ objective) confocal micrographs of cultured bovine granulosa cells showing selective nuclear accumulation of (a) pSmad-1 in response to 4-h exposure to BMP-4, BMP-6 and BMP-7 and (b) pSmad-2 in response to 4-h exposure to activin-A. Controls were stained with normal rabbit IgG in place of rabbit anti-pSmad-1/2 $\lg \mathrm{G}$. 

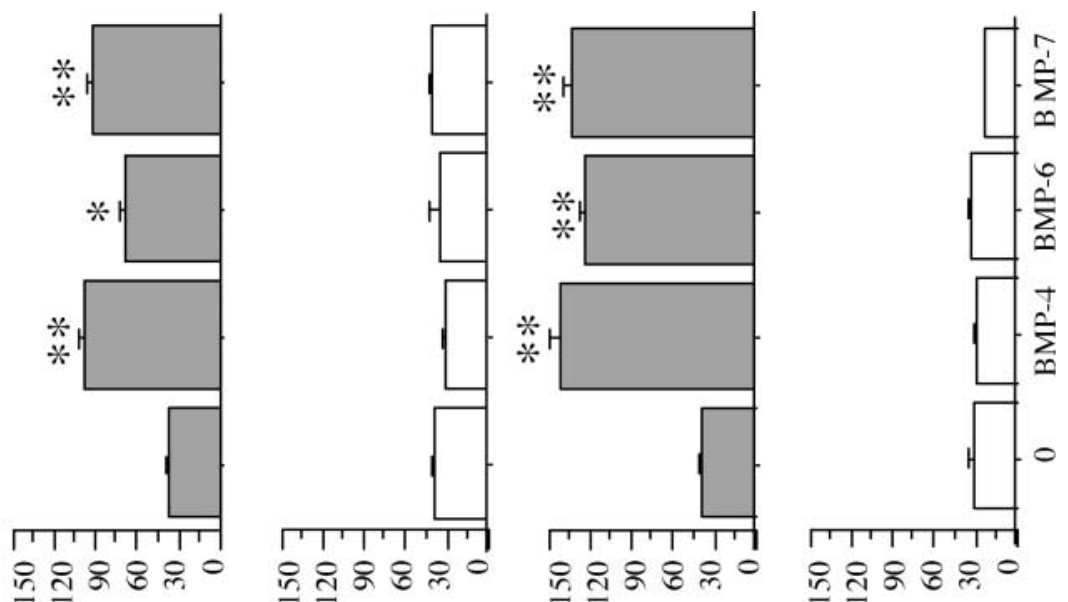

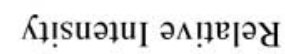
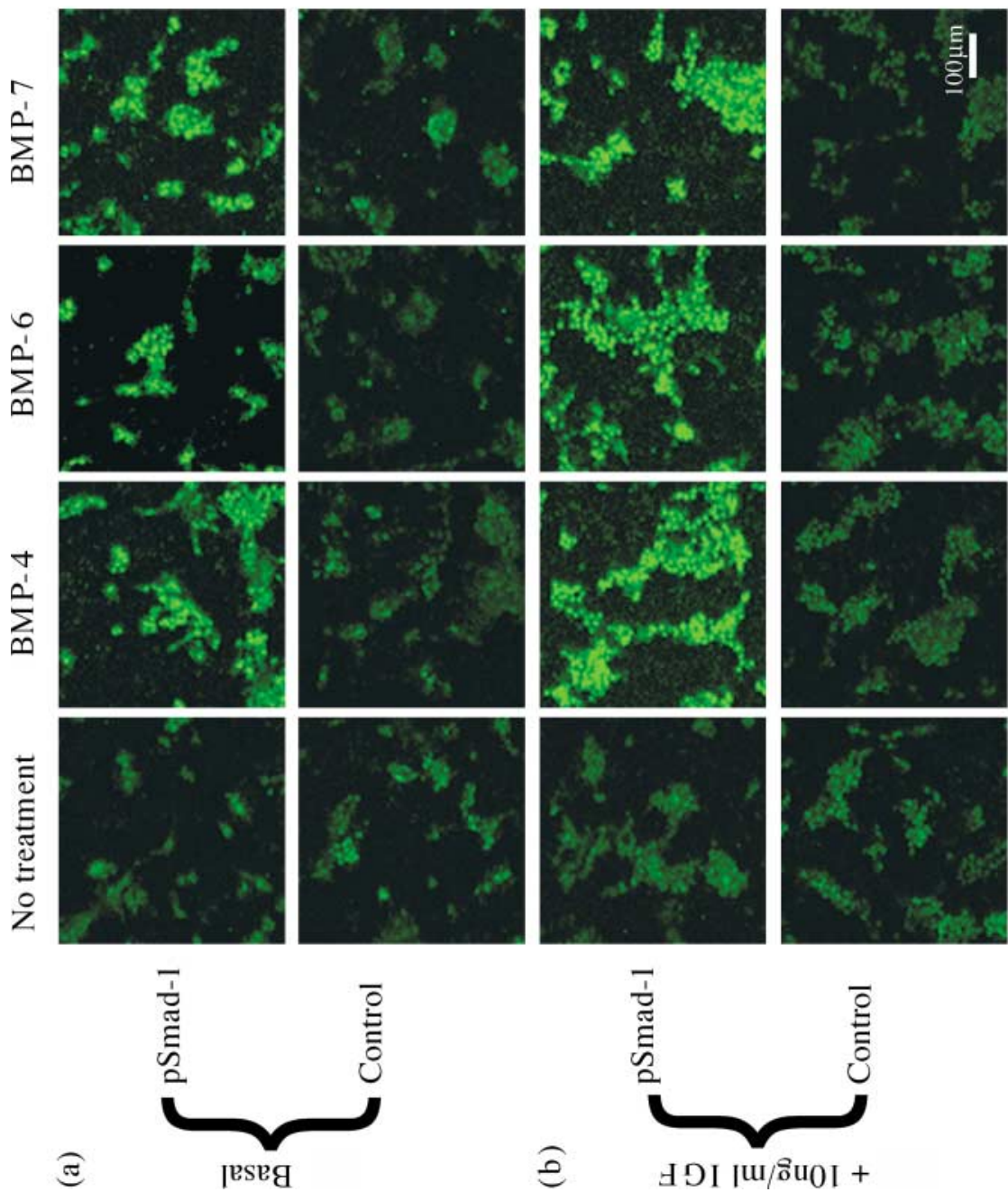

Figure 5 Representative low power ( $\times 16$ objective) confocal micrographs showing that 4-h exposure to BMP-4, BMP-6 and BMP-7 induces accumulation of pSmad-1 in bovine granulosa cells cultured (a) under 'basal' conditions and (b) with LR3-IGF-I. Controls were stained with normal rabbit IgG in place of rabbit anti-pSmad-1 IgG. The histograms aligned with each row show the results of quantitative assessment of relative fluorescence intensity of cells stained with anti-pSmad- $1 \mathrm{IgG}$ and normal rabbit IgG. Values are means \pm S.E.M. $(n=20$ randomly selected fields). $* P<0.001, * * P<0.0001$ compared with controls (no BMP). The results shown are representative of three replicate experiments. 
When cells were cultured in the presence of IGF all three BMPs caused significant enhancement of pSmad- 1 levels $(P<0.0001)$, with a $>3$-fold increase in staining intensity relative to controls (Fig. 5b). Moreover, cells given IGF stimulation throughout culture prior to BMP exposure showed elevated responses in terms of BMP-induced pSmad-1 accumulation (BMP $\times$ IGF treatment interaction, $P<0.001$; two-way ANOVA). As shown in Fig. 6, whilst treatment of granulosa cells with activin-A resulted in pSmad-2 accumulation, no such elevation in pSmad-1 levels were observed. Likewise, treatment with BMP $-4,-6$ or -7 increased pSmad-1 levels, but no corresponding increase in pSmad-2 occurred relative to controls. This confirms that minimal crossover occurs with regard to pSmad-1/2 activation by BMPs or activin respectively.

\section{The use of Biacore SPR to compare binding affinity of FS for activin-A and BMPs}

Figure 7 shows a representative kinetic sensorgram of the BMP-4 interaction with immobilized FS as monitored using SPR (Biacore). From the association and dissociation rate constants, the $K_{\mathrm{d}}$ of FS for activin, BMP-4, BMP- 6 and BMP-7 were calculated (Table 1). The affinity of FS for activin (mean $\left.K_{\mathrm{d}} 0.3 \mathrm{nM}\right)$ was significantly $(P<0.05)$ greater than that for all three BMPs tested. The $K_{\mathrm{d}}$ values of BMP-4 and -6 for FS were not significantly different ( $3 \mathrm{nM}$ and $5 \mathrm{nM}$ respectively); however, the $K_{\mathrm{d}}$ of BMP-7 for FS was significantly higher $(37 \mathrm{nM} ; P<0.05)$. When the affinities of FS for BMPs were expressed relative to its affinity for activin $(=100 \%)$, BMP $-4,-6$ and -7 gave values of $\sim 10,5$ and $1 \%$ respectively.

\section{Does FS inhibit BMP-or activin-A-induced Smad phosphorylation in granulosa cells?}

Treatment with activin-A alone increased $(P<0.001)$ the amount of pSmad-2 detected in cells (Fig. 8a). Co-treatment with FS resulted in a significant dose-dependent decrease in activin-A-stimulated Smad-2 phosphorylation $(P<0.0001)$. Indeed, the highest dose of FS used in combination with activin decreased the amount of pSmad-2 to below levels observed in untreated cells $(P<0.05)$. FS treatment in the absence of activin- $\mathrm{A}$ also dose-dependently reduced $\mathrm{pSmad}-2$ levels below those seen in untreated cells $(P<0.05)$. Treatment with BMP-4, -6 and -7 alone increased the amount of pSmad- 1 detected in cells (Fig. 8b, c and d respectively). Whilst BMP-4induced pSmad-1 activation was dose-dependently suppressed by both doses of FS, the lower dose of FS did not attenuate BMP-6-induced Smad-1 phosphorylation; however, the higher dose did have a suppressive effect $(P<0.0001)$. In contrast, BMP-7-induced Smad-1 phosphorylation was not reduced in the presence of either dose of FS; indeed it was significantly elevated $(P<0.05)$. In addition, in the absence of BMPs, a small yet significant $(P<0.05)$ increase in $\mathrm{pSmad}-1$ level was promoted by FS.

\section{Discussion}

This study has provided comprehensive evidence for a functional BMP signalling system within bovine antral follicles. Multiple BMP ligands and type-I and -II receptor subtypes were identified in theca cells, granulosa cells and oocytes and BMP-induced biological responses were demonstrated in granulosa cells including Smad-1 phosphorylation, modulation of steroid (E2, P4) and peptide (inhibin-A, activin-A, FS) secretion and stimulation of cell number. In addition, evidence is presented that FS acts as a functional BMP-binding protein, exhibiting differential binding affinity for the three BMPs examined.

The distribution of immunoreactive BMP-4, -6 and -7 that we observed amongst bovine follicle cell types is consistent with previous mRNA expression studies in rodents. Thus, expression of BMP-4 and -7 mRNA has been reported in rat theca cells (Shimasaki et al. 1999, Lee et al. 2001) while expression of BMP-6 mRNA has been reported in mouse oocytes (Elvin et al. 2000). Correspondingly, in this study immunoreactive BMP-4 and -7 were confined to theca cells whereas BMP-6 was abundant in both oocyte and granulosa cells. To our knowledge, granulosa cell expression of BMP-6 has not been reported previously in any species. This distinct distribution pattern of BMP ligands amongst theca, granulosa and oocyte compartments highlights possible diverse roles in cell-cell communication within the follicle. This is reinforced by our finding of BMPRIB and BMPRII expression on all three cell types.

In agreement with mRNA expression studies in rat (Shimasaki et al. 1999) and immunohistochemical evidence in sheep (Souza et al. 2002), BMPRIB and BMPRII immunoreactivity was less abundant in theca cells than in granulosa cells or oocytes. On the other hand, theca cells contained high levels of ActRIA, ActRIIA and ActRIIB immunoreactivity - three other receptors for TGF $\beta$ superfamily ligands through which BMPs can signal. Could this indicate preferential expression by theca cells of receptor subtypes favouring activin signalling in preference to BMP signalling? While it is well established that activin can suppress luteinizing hormone- and inhibin-induced androgen production by theca cells (rat: Hsueh et al. 1987, human: Hillier 1991, bovine: Wrathall \& Knight 1995) we are aware of only one study, involving a human ovarian theca-like tumour cell line (Dooley et al. 2000), implicating BMPs in the modulation of theca cell function. The latter study showed that BMP-4, like activin, suppressed androgen secretion by down-regulating expression of $17 \alpha-$ hydroxylase. Considerable heterogeneity of receptor staining was observed amongst individual oocytes, presumably reflecting differential receptor expression according to the size/health of the follicle from which they originated, and thus associated with oocyte maturational status.

Activin signalling occurs when the ligand binds to and forms a heteromeric complex with any combination of activin type-I (ActRIA, IB) and activin type-II (ActRIIA, IIB) 

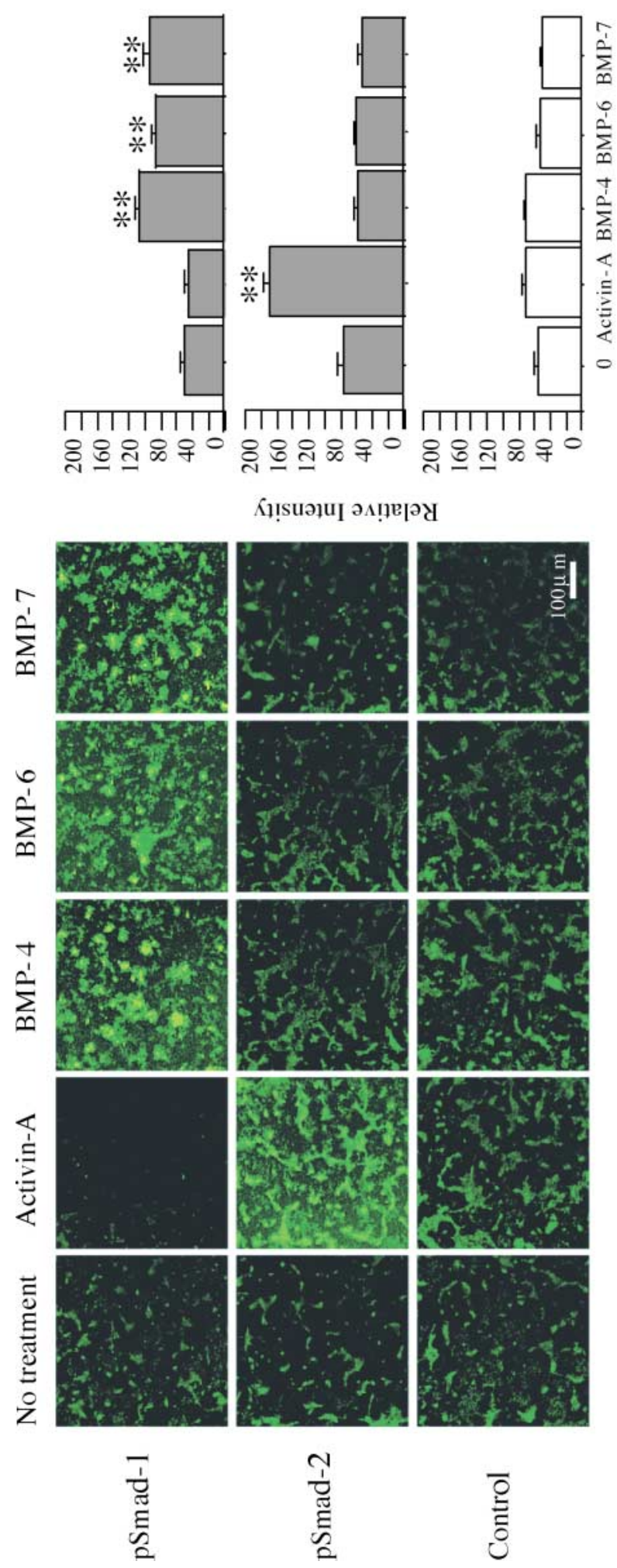

Figure 6 Representative low power $(\times 16$ objective) confocal micrographs showing that 4-h exposure of bovine granulosa cells to activin-A selectively induces pSmad-2 accumulation while exposure to BMP-4, BMP-6 and BMP-7 selectively induce pSmad- 1 accumulation. Controls were stained with normal rabbit IgG in place of anti-pSmad-1/2 IgG. The histograms aligned with each row show the results of quantitative assessment of relative fluorescence intensity of cells stained with anti-pSmad-1 IgG, anti-pSmad-2 and normal rabbit lgG. Values are means \pm S.E.M. $\left(n=20\right.$ randomly selected fields). ${ }^{* * P}<0.0001$ compared with controls (no treatment). The results shown are representative of three replicate experiments. 


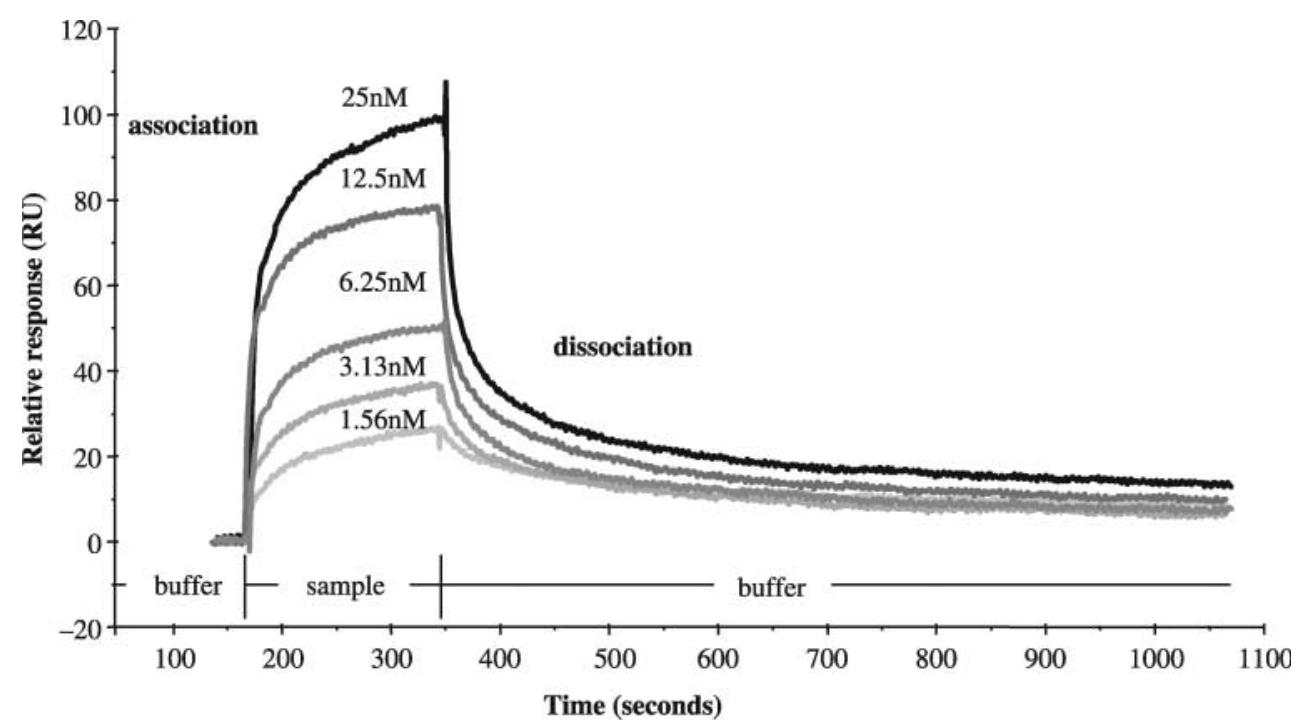

Figure 7 Representative Biacore SPR 'sensorgrams' showing the interaction in real time of BMP-4 at a range of concentrations (1.56-25 nM) with immobilized FS covalently bound to the surface of a CM5 sensorchip. RU, resonance units.

receptors on the cell surface. BMPs interact with a more diverse array of type-I (BMPRIA, BMPRIB, ActRIA) and type-II (BMPRII, ActRIIA, ActRIIB) receptors (Kawabata et al. 1998, Macias-Silva et al. 1998, Ebisawa et al. 1999, Peng \& Mukai 2000). The different combinatorial patterns of receptor recruitment possible for BMP signalling highlights both the intrinsic complexity of the signalling system and a likely element of redundancy that exists with regard to functional BMP ligand-receptor interactions.

The present study only examined the expression of BMP ligands and receptors in isolated granulosa cells, theca cells and oocytes collected from medium-sized antral follicles from randomly cycling cow ovaries. Further studies involving comprehensive immunohistochemical and in situ hybridization analyses of ovarian sections from cattle at different stages of the oestrous cycle would be valuable in confirming the physiological relevance of these findings. Such studies would also provide information on BMP ligand/receptor expression at other stages of folliculogenesis and in ovarian compartments (i.e. stroma, corpus luteum, cumulus cells, surface epithelium) not investigated in the present study. Such evidence from rat ovaries

Table 1 Comparison of the $K_{d}$ values (means \pm S.E.M. based on three independent Biacore experiments) and relative binding affinities of four TGF $\beta$ superfamily members (activin-A, BMP-4, BMP-6 and BMP-7) for FS as determined by Biacore (SPR).

\begin{tabular}{lcc}
\hline Ligand & $\boldsymbol{K}_{\mathbf{d}}(\mathrm{nM})$ & Relative affinity $(\%)$ \\
\hline Activin-A & $0.28 \pm 0.02^{\mathrm{a}}$ & 100 \\
BMP-4 & $2.9 \pm 1.2^{\mathrm{b}}$ & 9.7 \\
BMP-6 & $5.1 \pm 1.2^{\mathrm{b}}$ & 5.5 \\
BMP-7 & $37 \pm 25^{\mathrm{C}}$ & 0.8 \\
\hline
\end{tabular}

Values with different superscripts are significantly $(P<0.05)$ different. suggests that expression of mRNA for BMP-4 and -7 is restricted to the theca layer of healthy follicles and that BMPRII mRNA is most abundant in granulosa cells after the secondary follicle stage (Shimasaki et al. 1999). Although the stage of the oestrous cycle was not defined, Souza et al. (2002) recently reported that, in sheep, BMPRIA, BMPRIB and BMPRII were strongly expressed in the granulosa layer and oocyte of follicles from the primary to preovulatory stages; weaker immunostaining was observed in theca cells and staining was absent from stromal tissue.

The expression of BMPRs in oocytes suggests intrafoIlicular roles for BMPs in modulating oocyte development and maturation. Activin-A, a related TGF $\beta$ superfamily member expressed mainly by granulosa cells, has been shown to enhance bovine oocyte maturation and developmental competence in an FS-reversible manner (Stock et al. 1997, Silva \& Knight 1998). This action is consistent with the present finding of activin type-I and -II receptors on bovine oocytes. However, to our knowledge, functional studies to examine potential effects of BMPs on oocyte developmental competence have not been reported.

The effects of BMP-4, -6 or -7 on granulosa cells and their interactions with IGF co-treatment have not been explored previously in cattle. However, recent studies have reported BMP actions on steroidogenesis in rat granulosa cells (Lee et al. 2001, Otsuka et al. 2001a). In contrast to these rat studies in which BMPs did not modulate 'basal' steroid secretion we found that all three BMPs tested on bovine granulosa cells enhanced both 'basal' and IGF-stimulated E2 secretion with a concomitant decrease in basal and IGF-stimulated P4 secretion. Moreover, contrary to the lack of effect of BMP- 6 and -7 on proliferation of rat granulosa cells (Lee et al. 2001, 

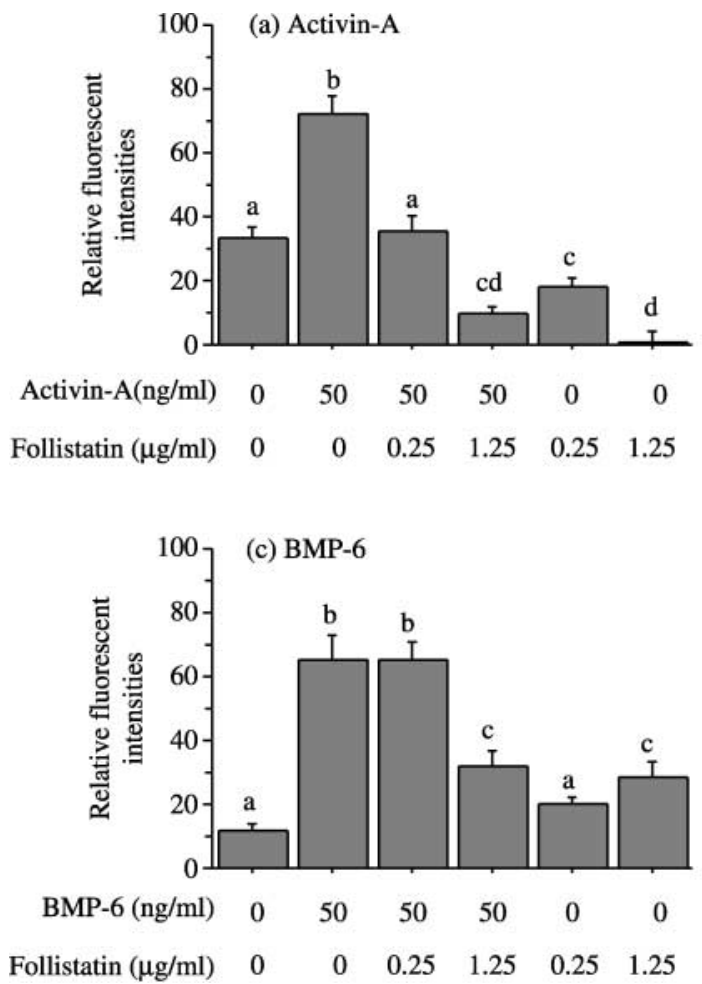
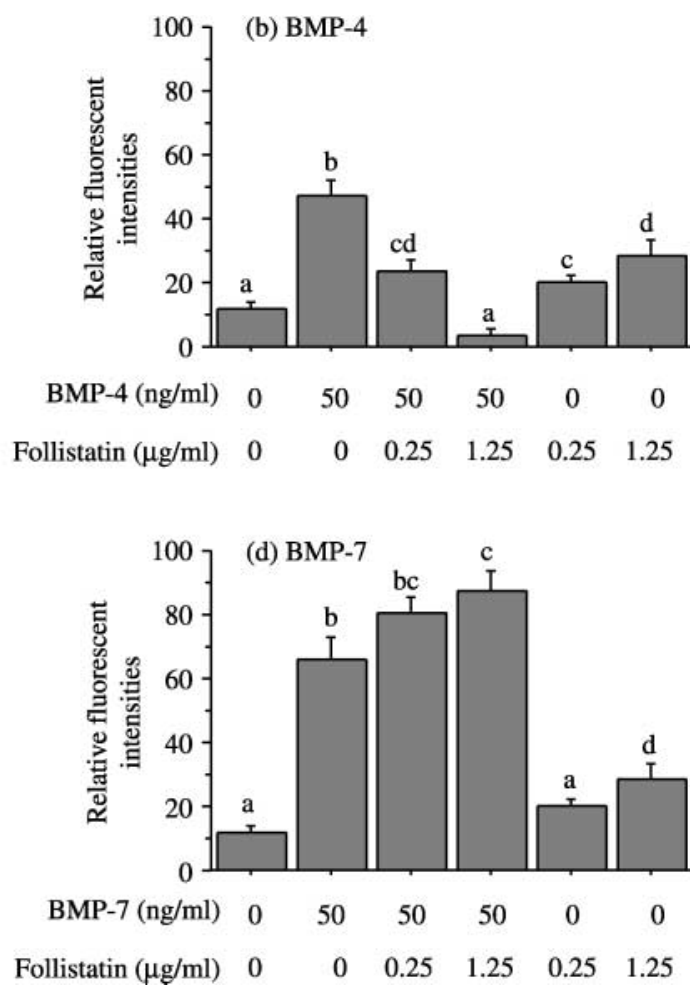

Figure 8 Comparison of the relative fluorescence intensity of cultured bovine granulosa cells immunostained with (a) pSmad-2 or (b-d) pSmad-1 antibodies after 4-h exposure to different combinations of ligand (activin/BMP; 0 or $50 \mathrm{ng} / \mathrm{ml}$ ) and binding protein (FS; 0, 0.25 , $1.25 \mathrm{\mu g} / \mathrm{ml}$ ). Panel (a) shows that activin-A-induced accumulation of pSmad-2 is completely blocked by FS and that FS alone reduces 'basal' pSmad-2 levels, (b) shows that BMP-4-induced pSmad-1 accumulation is completely blocked by FS although FS alone increased 'basal' pSmad-1 level, (c) shows that BMP-6-induced pSmad-1 accumulation is only partially blocked by FS while (d) shows that FS did not antagonize BMP-7-induced pSmad-1 accumulation but caused a slight enhancement. Mean relative fluorescence intensity values of corresponding sets of control cells immunostained with normal $\operatorname{lgG}$ (i.e. background values) have been subtracted. Values are means \pm S.E.M. $(n=20$ randomly selected fields). Bars without a common letter are significantly different. The results shown are from one of three replicate experiments.

Otsuka et al. 2001a), treatment of bovine granulosa cells with BMP-6 and -7 alone promoted a modest though significant increase in viable cell number. Indeed, when cells were co-treated with IGF analogue all three BMPs tested significantly increased viable cell number by $\sim 35 \%$.

This study is the first to report the concomitant effects of BMPs on the secretion of steroids (E2, P4) and activin-A, FS and inhibin-A by granulosa cells from any species. As we observed for E2 secretion, all three BMPs tested promoted similar dose-dependent increases in secretion of activin-A, FS and inhibin-A. This response was evident both under 'basal' conditions and when cells were co-treated with IGF which, alone, greatly enhanced E2 and peptide secretion as reported previously (Glister et al. 2001). Another BMP (BMP-2) was recently shown to promote E2 and inhibin-A secretion from sheep granulosa cells (Souza et al. 2002) with which our findings are consistent, whilst in human granulosa-lutein cells BMP-2 enhanced expression of mRNA for inhibin- $\beta B$ subunit, but not $-\beta A$ or $-\alpha$ subunit (Jaatinen et al. 2002). However, the presence of endogenous BMP-2 within sheep or human ovary has yet to be confirmed.
As reported previously (Gutiérrez et al. 1997, Glister et al. 2001, 2003), bovine granulosa cells cultured under the present serum-free conditions maintain a 'follicular' phenotype (i.e. prominent cellular clumping; maintenance of aromatase activity; high responsiveness to folliclestimulating hormone/IGF in terms of E2 and inhibin-A production) rather than a luteinized phenotype characteristic of cells cultured in serum-supplemented medium. The observation that all three BMPs tested increase E2 and inhibin-A, whilst suppressing P4, indicates that BMPs have an anti-luteolytic effect in this system. Therefore, BMPs from the oocyte (BMP-6), theca cells (BMP-4 and -7) and/or granulosa cells themselves (BMP-6) may act in concert with other systemic and locally produced factors (e.g. FS, IGF, activin) to maintain an oestrogen-active follicular status and delay the onset of atresia and/or luteinization. While information is currently lacking, it is likely that the pattern of expression of different BMP ligands and receptors in different ovarian cell types varies considerably throughout follicular maturation, reflecting more subtle developmental roles than those implied by the present findings for mid-antral follicles. For example, oocyte-derived BMP-15 (GDF-9B) and GDF-9 play an 
essential role in the early stages of follicle development (primordial to primary transition) to promote granulosa cell proliferation and prevent differentiation (Dong et al. 1996, Vitt et al. 2000). However, they continue to be expressed through to the large antral stage and recent evidence from immunoneutralization studies in sheep suggests that BMP-15 is required for follicle development to the ovulatory stage (Juengel et al. 2002).

The present results suggest that BMP-4, -6 and -7 modulate a biochemical pathway(s) within bovine granulosa cells resulting in simultaneous up-regulation of cytochrome P450 aromatase enzyme (P450arom) activity (E2 production), inhibin-A, activin-A and FS production and suppression of $\mathrm{P} 4$ production. With regards to effects on steroidogenesis, recent studies in rats indicate that BMPs can suppress steroid acute regulating protein (StAR) and cytochrome P450 side-chain cleavage enzyme (P450scc) expression giving rise to a decrease in P4, whilst enhancing P450arom expression leading to elevated E2 (Lee et al. 2001, Otsuka et al. 2001a). However, the picture appears more complex than implied by our findings in the bovine since different BMPs appear to exert different biological effects on rat granulosa cell steroidogenesis. Thus, BMP-6 and -7 both suppress StAR expression while BMP-6 (but not BMP-7) suppresses P450scc (Lee et al. 2001, Otsuka et al. 2001a); conversely, BMP-7 (but not BMP-6) enhances P450arom (Lee et al. 2001, Otsuka et al. 2001a). Moreover, BMP-15, secreted exclusively by the oocyte, suppresses StAR, P450scc and P450arom expression (Otsuka et al. 2001b). To our knowledge the effect of BMP-4 has not previously been tested on granulosa cells from any species.

As well as demonstrating expression of BMPRs on bovine granulosa cells, this study has shown that these receptors can bind and form functional signalling complexes with BMP-4, -6 and -7 leading to activation of a Smad-mediated intracellular transduction pathway and a cellular response in terms of altered steroidogenesis, peptide hormone secretion and proliferation. Whilst activin signalling is transduced predominantly via a Smad-2 pathway, BMPs utilize Smad-1 and -5 pathways (Ebisawa et al. 1999, Miyazono et al. 2000, Peng \& Mukai 2000, Miyazawa et al. 2002). Using a quantitative immunocytochemical approach we showed that addition of all three BMPs to cultured bovine granulosa cells activated the Smad-1 pathway, as reflected by cellular accumulation of pSmad-1 immunoreactivity; BMPs had no effect on the levels of pSmad-2 detected in the cells. Conversely, activin-A treatment promoted cellular accumulation of pSmad-2 but had no effect on pSmad-1 level, confirming the expected ligand-specific pattern of Smad activation (Miyazawa et al. 2002). Interestingly, both BMP-induced changes in hormone secretion and BMP-induced pSmad-1 accumulation were more pronounced in cells treated with IGF, raising the possibility that activation of IGF receptors up-regulates the BMP signalling pathway, perhaps through enhanced expression of BMPRs on the cell surface. Further work is required to explore this possibility.

The ability of FS to bind to and neutralize the biological actions of activin has been well documented (Xiao et al. 1992, Findlay 1993, Woodruff 1998, Knight \& Glister 2001). More recent studies indicate that FS can also bind BMPs. Whilst there are reports of BMP-2, $-4,-7$ and -15 binding to FS (lemura et al. 1998, Otsuka et al. 2001c, Amthor et al. 2002), the results of which are consistent with those reported here, no previous report of BMP-6 binding to FS exists. Furthermore, we have revealed that FS has differential binding affinities for the different BMPs, with its affinity for activin-A, its 'prototype' ligand, being the highest. A previous study also reported that the affinity of FS for activin-A was considerably greater than for BMP-4 (lemura et al. 1998).

We also compared the relative binding affinities of FS for activin-A and BMP-4, -6 and -7 with its ability to bioneutralize ligand-induced pSmad-2 (activin) or pSmad-1 (BMPs) accumulation. At the dose levels tested FS could completely neutralize activin-A-induced Smad-2 activation. However, FS had a progressively lesser effect on Smad- 1 activation induced by BMP-4 and -6 and was completely ineffective in neutralizing the response to BMP-7. Indeed, co-treatment of cells with FS and BMP-7 led to a small though statistically significant increase in pSmad- 1 level. This finding raises the possibility that lowaffinity association with FS may actually enhance the interaction of BMP-7 with its cognate receptors, perhaps by maintaining higher concentrations of ligand near the cell surface, to which FS can bind via membraneanchored proteoglycans (Nakamura et al. 1991). Thus, in physiological terms, local intrafollicular actions of thecaderived BMP-7 are unlikely to be neutralized by endogenous FS whereas the actions of BMP-4 and -6 may be, as is certainly the case for activins.

Given that FS binds to BMP-4, -6 and -7 with different affinities (activin-A $>$ BMP-4 $>$ BMP-6 $>$ BMP-7) it might be unexpected that each BMP had comparable effects on pSmad-1 accumulation and modulation of steroidogenesis, peptide production and cell proliferation when tested on bovine granulosa cells. However, endogenous levels of FS measured in bovine granulosa cell-conditioned media would most likely be insufficient to bioneutralize exogenous BMP (maximum dose level tested: $50 \mathrm{ng} / \mathrm{ml}$ or $\sim 1.4 \mathrm{nmol} / \mathrm{l}$ ) given that (i) endogenous activin-A levels ( $\sim 0.5-1$ and $\sim 2-5 \mathrm{nmol} / \mathrm{l}$ under basal and IGF-stimulated conditions respectively) were in excess of endogenous FS levels $(\sim 0.3-0.6$ and $\sim 0.7-1.4 \mathrm{nmol} / \mathrm{l}$ under 'basal' and IGF-stimulated conditions respectively), (ii) activin binds to FS on a 2:1 molar ratio, (iii) the affinity of FS for activin $\left(K_{\mathrm{d}} 0.28 \mathrm{nM}\right)$ is $>10$-fold greater than for any of the BMPs tested and (iv) the affinity of BMPs for their receptors is presumably much greater than their affinity for FS. Since no information is yet available (for any species) on the endogenous concentrations of BMPs in follicular fluid or granulosa cell-conditioned media, it is 
not possible to draw definitive conclusions on the extent to which they interact with endogenous FS or other binding proteins.

Treatment of granulosa cells with FS in the absence of exogenous activin-A or BMPs led to reduced accumulation of pSmad-2, presumably reflecting bioneutralization of endogenous activin(s) secreted by the cells (Glister et al. 2001). In marked contrast, FS treatment alone increased accumulation of pSmad-1, raising the suggestion that FS may enhance presentation of endogenous BMP to its receptor(s) on the granulosa cell surface. Collectively, these data support a model in which FS may function as either an antagonist and/or enhancer of BMP signalling within granulosa cells, depending on its relative binding affinity for different BMPs and activin-A and on the relative concentrations of FS and each ligand present. As yet there is a paucity of information on the factors regulating the synthesis and secretion of individual BMPs by different ovarian cell types, on the intrafollicular concentrations of BMPs and on the spatio-temporal patterns of BMP and BMPR expression during folliculogenesis in the bovine ovary. Such information will ultimately be required to fully evaluate the physiological roles of the ovarian BMP system.

\section{Acknowledgements}

We are grateful to Mr S A Feist and Miss A L Morgan for technical assistance, Professor N P Groome (Oxford Brookes University, Oxford, UK) for providing monoclonal antibodies for inhibin, activin-A and FS assays, Dr A Parlow (NHPP, Torrance, CA, USA) for recombinant human FS, and NIBSC (Potters Bar, Herts, UK) for rh inhibin-A and activin-A reference preparations. This work was supported by the BBSRC.

\section{References}

Adashi EY, Resnick CE, Hurwitz A, Ricciarellie E, Hernandez ER, Roberts CT, Leroith D \& Rosenfeld R 1992 The intra-ovarian IGF system. Growth Regulation 2 10-15.

Amthor H, Christ B, Rashid-Doubell F, Kemp CF, Lang E \& Patel K 2002 Follistatin regulates bone morphogenetic protein-7 (BMP-7) activity to stimulate embryonic muscle growth. Developmental Biology 243 115-127.

Bodensteiner KJ, Clay CM, Moeller CL \& Sawyer HR 1999 Molecular cloning of the ovine growth/differentiation factor-9 gene and expression of growth/differentiation factor-9 in ovine and bovine ovaries. Biology of Reproduction $60381-386$.

Campbell BK, Scaramuzzi RJ \& Webb R 1996 Induction and maintenance of oestradiol and immunoreactive inhibin production with FSH by ovine granulosa cells cultured in serum-free media. Journal of Reproduction and Fertility 106 7-16.

Dong J, Albertini DF, Nishimori K, Kumar TR, Lu N \& Matzuk MM 1996 Growth differentiation factor-9 is required during early ovarian folliculogenesis. Nature 383 531-535.

Dooley CA, Attia GR, Rainey WE, Moore DR \& Carr BR 2000 Bone morphogenetic protein inhibits ovarian androgen production. Journal of Clinical Endocrinology and Metabolism 85 3331-3337.

Ebisawa T, Tada K, Kitajima I, Tojo K, Sampath K, Kawabata M, Miyazono K \& Imamura T 1999 Characterization of bone morphogenetic protein-6 signaling pathways in osteoblast differentiation. Journal of Cell Science 112 3519-3527.
Elvin JA, Clark AT, Wang P, Wolfman NM \& Matzuk MM 1999 Paracrine actions of growth differentiation factor-9 in the mammalian ovary. Molecular Endocrinology 13 1035-1048.

Elvin JA, Yan C \& Matzuk MM 2000 Oocyte-expressed TGF-beta superfamily members in female fertility. Molecular and Cellular Endocrinology 159 1-5.

Findlay JK 1993 An update on the roles of inhibin, activin, and follistatin as local regulators of folliculogenesis. Biology of Reproduction 48 15-23.

Galloway SM, McNatty KP, Cambridge LM, Laitinen MP, Juengel JL, Jokiranta TS, McLaren RJ, Luiro K, Dodds KG, Montgomery GW, Beattie AE, Davis GH \& Ritvos O 2000 Mutations in an oocytederived growth factor gene (BMP15) cause increased ovulation rate and infertility in a dosage-sensitive manner. Nature Genetics 25 279-283.

Glister C, Tannetta DS, Groome NP \& Knight PG 2001 Interactions between follicle-stimulating hormone and growth factors in modulating secretion of steroids and inhibin-related peptides by nonluteinized bovine granulosa cells. Biology of Reproduction $\mathbf{6 5}$ 1020-1028.

Glister C, Groome NP \& Knight PG 2003 Oocyte-mediated suppression of follicle-stimulating hormone- and insulin-like growth factor-induced secretion of steroids and inhibin-related proteins by bovine granulosa cells in vitro: possible role of transforming growth factor $\alpha$. Biology of Reproduction 68 758-765.

Gutiérrez CG, Campbell BK \& Webb R 1997 Development of a long-term bovine granulosa cell culture system: induction and maintenance of estradiol production, response to follicle-stimulating hormone, and morphological characteristics. Biology of Reproduction 56 608-616.

Hillier SG 1991 Regulatory functions for inhibin and activin in human ovaries. Journal of Endocrinology 131 171-175.

Hsueh AJ, Dahl KD, Vaughan J, Tucker E, Rivier J, Bardin CW \& Vale W 1987 Heterodimers and homodimers of inhibin subunits have different paracrine action in the modulation of luteinizing hormone-stimulated androgen biosynthesis. PNAS 84 5082-5086.

lemura S, Yamaoto TS, Takagi C, Uchiyama H, Natsume T, Shimasaki S, Sugino H \& Ueno N 1998 Direct binding of follistatin to a complex of bone-morphogenetic protein and its receptor inhibits ventral and epidermal cell fates in early Xenopus embryo. Developmental Biology 95 9337-9342.

Jaatinen R, Rosen V, Tuuri T \& Ritvos O 1996 Identification of ovarian granulosa cells as a novel site of expression for bone morphogenetic protein-3 (BMP-3/osteogenin) and regulation of BMP-3 messenger ribonucleic acids by chorionic gonadotropin in cultured human granulosa-luteal cells. Journal of Clinical Endocrinology and Metabolism 81 3877-3882.

Jaatinen R, Laitinen MP, Vuojolainen K, Aaltonen J, Heikinheimo K, Lehtonen E \& Ritvos O 1999 Localization of growth differentiation factor-9 (GDF-9) mRNA and protein in rat ovaries and cDNA cloning of rat GDF-9 and its novel homolog GDF-9B. Molecular and Cellular Endocrinology 156 189-193.

Jaatinen R, Bondestam J, Raivio T, Hilden K, Dunkel L, Groome N \& Ritvos O 2002 Activation of the bone morphogenetic protein signaling pathway induces inhibin $\beta_{B}$-subunit mRNA and secreted inhibin B levels in cultured human granulosa-luteal cells. Journal of Clinical Endocrinology and Metabolism 87 1254-1261.

Juengel JL, Hudson NL, Heath DA, Smith P, Reader KL, Lawrence SB, O'Connell AR, Laitinen MP, Cranfield M, Groome NP, Ritvos O \& McNatty KP 2002 Growth differentiation factor 9 and bone morphogenetic protein 15 are essential for ovarian follicular development in sheep. Biology of Reproduction 67 1777-1789.

Kawabata M, Imamura T \& Miyazono K 1998 Signal transduction by bone morphogenetic proteins. Cytokine and Growth Factor Reviews 9 49-61.

Knight PG \& Muttukrishna S 1994 Measurement of dimeric inhibin using a modified two-site immunoradiometric assay specific for oxidized (Met O) inhibin. Journal of Endocrinology 141 $417-425$. 
Knight PG \& Glister C 2001 Potential local regulatory functions of inhibins, activins and follistatin in the ovary. Reproduction 121 503-512.

Knight PG, Muttukrishna S \& Groome NP 1996 Development and application of a two-site enzyme immunoassay for the determination of 'total' activin-A concentrations in serum and follicular fluid. Journal of Endocrinology 148 267-279.

Lee WS, Otsuka F, Moore RK \& Shimasaki S 2001 Effect of bone morphogenetic protein-7 on folliculogenesis and ovulation in the rat. Biology of Reproduction 65 994-999.

McGrath SA, Esquela AF \& Lee S 1995 Oocyte-specific expression of growth/differentiation factor-9. Molecular Endocrinology 9 131-136.

Macias-Silva M, Hoodless PA, Tang SJ, Buchwald M \& Wrana JL 1998 Specific activation of Smad1 signaling pathways by the BMP7 type I receptor, ALK2. Journal of Biological Chemistry 273 25628-25636.

McNatty KP, Juengel JL, Wilson T, Galloway SM \& Davis GH 2001 Genetic mutations influencing ovulation rate in sheep. Reproduction, Fertility and Development 13 549-555.

Massague J \& Chen YG 2000 Controlling TGF-beta signaling. Genes and Development 14 627-644.

Miyazawa K, Shinozaki M, Hara T, Furuya T \& Miyazono K 2002 Two major Smad pathways in TGF- $\beta$ superfamily signalling. Genes to Cells 7 1191-1204.

Miyazono K, ten Dijke P \& Heldin CH 2000 TGF-beta signaling by Smad proteins. Advances in Immunology 75 115-157.

Nakamura T, Sugino K, Titani K \& Sugino H 1991 Follistatin: an activin-binding protein, associates with heparin sulphate chains of proteoglycans on follicular granulosa cells. Journal of Biological Chemistry $26619432-19437$.

Otsuka F, Yao Z, Lee T, Yamamoto S, Erickson GF \& Shimasaki S 2000 Bone morphogenetic protein-15. Journal of Biological Chemistry 275 39523-39528.

Otsuka F, Moore RK \& Shimasaki S 2001a Biological function and cellular mechanism of bone morphogenetic protein- 6 in the ovary. Journal of Biological Chemistry 276 32889-32895.

Otsuka F, Yamamoto S, Erickson GF \& Shimasaki S $2001 b$ Bone morphogenetic protein-15 inhibits follicle-stimulating hormone (FSH) action by suppressing FSH receptor expression. Journal of Biological Chemistry 276 11387-11392.

Otsuka F, Moore RK, lemura S, Ueno N \& Shimasaki S 2001c Follistatin inhibits the function of the oocyte-derived factor BMP-15. Biochemical and Biophysical Research Communications 289 961-966.

Peng C \& Mukai ST 2000 Activins and their receptors in female reproduction. Biochemistry and Cell Biology 78 261-279.

Sauer MJ, Foulkes JA, Worsfold A \& Morris BA 1986 Use of progesterone 11-glucuronide-alkaline phosphatase conjugate in a sensitive microtitre-plate enzymeimmunoassay of progesterone in milk and its application to pregnancy testing in dairy cattle. Journal of Reproduction and Fertility 76 375-391.
Shimasaki S, Zachow RJ, Li D, Kim H, lemura S, Ueno N, Sampath K, Chang RJ \& Erickson GF 1999 A functional bone morphogenetic protein system in the ovary. PNAS $967282-7287$.

Silva CC \& Knight PG 1998 Modulatory actions of activin-A and follistatin on the developmental competence of in vitro-matured bovine oocytes. Biology of Reproduction 58 558-565.

Souza CJ, MacDougall C, MacDougall C, Campbell BK, McNeilly AS \& Baird DT 2001 The Booroola (FecB) phenotype is associated with a mutation in the bone morphogenetic receptor type $1 \mathrm{~B}$ (BMPR1B) gene. Journal of Endocrinology 169 R1-R6.

Souza CJ, Campbell BK, McNeilly AS \& Baird DT 2002 Effect of bone morphogenetic protein-2 (BMP-2) on oestradiol and inhibinA production by sheep granulosa cells, and localization of BMP receptors in the ovary by immunohistochemistry. Reproduction $123363-369$.

Stock AE, Woodruff TK \& Smith LC 1997 Effects of inhibin A and activin A during in vitro maturation of bovine oocytes in hormoneand serum-free medium. Biology of Reproduction 56 1559-1564.

Tannetta DS, Feist SA, Bleach ECL, Groome NP, Evans LW \& Knight PG 1998 Effects of active immunization of sheep against an amino terminal peptide of the inhibin $\alpha \mathrm{C}$ subunit on intrafollicular levels of activin A, inhibin A and follistatin. Journal of Endocrinology 157 157-168.

Vitt UA, Hayashi M, Klein C \& Hsueh AJ 2000 Growth differentiation factor-9 stimulates proliferation but suppresses the follicle-stimulating hormone-induced differentiation of cultured granulosa cells from small antral and preovulatory rat follicles. Biology of Reproduction 62 370-377.

Webb R, Campbell BK, Gaverick HA, Gong JG, Gutierrez CG \& Armstrong DG 1999 Molecular mechanisms regulating follicular recruitment and selection. Journal of Reproduction and Fertility $\mathbf{5 4}$ $33-48$.

Wilson T, Wu XY, Juengel JL, Ross IK, Lumsden JM, Lord EA, Dodds KG, Walling GA, McEwan JC, O'Connell AR, McNatty KP \& Montgomery GW 2001 Highly prolific Booroola sheep have a mutation in the intracellular kinase domain of bone morphogenetic protein IB receptor (ALK-6) that is expressed in both oocytes and granulosa cells. Biology of Reproduction 64 1225-1235.

Woodruff TK 1998 Regulation of cellular and system function by activin. Biochemistry and Pharmacology 55 953-963.

Wrathall JH \& Knight PG 1995 Effects of inhibin-related peptides and oestradiol on androstenedione and progesterone secretion by bovine theca cells in vitro. Journal of Endocrinology 145 $491-500$

Xiao S, Robertson DM \& Findlay JK 1992 Effects of activin and follicle-stimulating hormone (FSH)-suppressing protein/follistatin on FSH receptors and differentiation of cultured rat granulosa cells. Endocrinology 131 1009-1016.

Received 5 June 2003

First decision 27 August 2003

Accepted 28 October 2003 